\title{
PHYSICOCHEMICAL CHARACTERIZATION OF JUSSARA PULP POWDER BY SPRAY-DRYING
}

\author{
AUDIRENE AMORIM SANTANA ${ }^{* * *, * * *}$ \\ RAFAEL AUGUSTUS DE OLIVEIRA** \\ VÂNIA REGINA NICOLETTI TELIS*
}

\begin{abstract}
This study was carried out to evaluate the effects of different mixtures of carrier agents (CA) (modified starch-MS plus whey protein concentrate-WPC or soy protein isolate-SPI) on the characteristics of microcapsules containing spray-dried jussara pulp powder. Four treatments, $30 \% \mathrm{CAC}+17.5 \% \mathrm{MS}: \mathrm{WPC}, 17.5 \% \mathrm{CAC}+30$ \%MS:WPC, $30 \% \mathrm{CAC}+17.5 \% \mathrm{MS}: \mathrm{SPI}$ and $17.5 \% \mathrm{CAC}+30$ $\% \mathrm{MS}: \mathrm{SPI}$, were evaluated, where $\mathrm{CAC}=$ carrier agent concentration (g carrier/g jussara pulp solids) and the proportions MS:WPC and MS:SPI indicate the grams of protein (WPC or SPI) per $100 \mathrm{~g}$ of carrier. The solubility of the particles was not affected by the wall material, attaining average values of $78 \%$. The concentration of 30 \%CAC+17.5 \%MS:WPC improved the bulk density and moisture content. WPC and SPI were shown to be good alternative secondary wall materials for jussara pulp, together with MS.
\end{abstract}

KEY-WORDS: EUTERPE EDULIS MARTIUS, SPRAY DRYING, WHEY PROTEIN CONCENTRATE, MODIFIED STARCH, SOY PROTEIN ISOLATE.

*Department of Food Engineering and Technology, State University Paulista (UNESP), Rua Cristóvão Colombo, 2265, São José do Rio Preto - SP, 15054-000, Brazil

${ }^{* *}$ Faculty of Agricultural Engineering, University of Campinas (UNICAMP), Avenida Candido Rondon, 501, Cidade Universitária Zeferino Vaz, Barão Geraldo, Campinas - SP, 13083-875, Brazil

${ }^{* * *}$ Faculty of Chemical Engineering, Federal University of Maranhão (UFMA), Avenida dos Portugueses, 1966, Bacanga, São Luís - MA, 65080-805, Brazil

* Corresponding author. Tel. and Fax: +55 9832729239.

E-mail address: audirene.amorim@gmail.com (Santana, A.A); augustus@feagri.unicamp.br (Oliveira, R.A.); vanianic@ibilce.unesp.br (Telis, V.R.N.). 


\section{INTRODUCTION}

The jussara palm (Euterpe edulis Martius) is widely distributed throughout the Brazilian Atlantic Forest and produces edible palm hearts and spherical fruits known as jussara. These fruits contain only one light brown seed and are covered by a thin, dry, shiny, dark purple skin, which, due to its high anthocyanin content, appears almost black in color when ripe (Borges et al., 2011). The jussara fruits are mostly used as pulp, which is consumed as such or used in different kinds of beverages, ice creams or sweets.

Although this fruit has good potential in the food industry as a result of its sensory and nutritional qualities, it is highly perishable. Moreover, seasonality is a factor that limits its commercialization and access to consumers. Furthermore, the anthocyanin compounds, responsible for the attractive color of jussara, are generally susceptible to degradation reactions during processing and storage, due to their sensitivity to adverse environmental conditions, such as high temperatures, light, and oxygen. In this context, the spray drying process represents an alternative to improve the conservation of the final product, and can result in a powder with greater stability and a longer shelf life, facilitating the storage, handling, and transportation of the product (Master, 1991; Ré, 1998). However, studies concerning the determination of the physicochemical properties of spray dried jussara powder have not yet been reported.

On the other hand, fruit juice powders obtained by spray drying may present some difficulties, such as stickiness, hygroscopicity and low solubility. In addition, the adhesion of droplets to the drying chamber walls decreases the process yield. According to Bhandari et al. (1997) the sticky behavior of sugar- and acid-rich materials is attributed to low-molecular-weight sugars and organic acids, which have low glass transition temperatures. One way of avoiding these problems is to add carrier agents before spray-drying, since their high molecular weights increase the glass transition temperature of the product. The most common carrier agents used in the spray drying of fruit pulps are starches and their derivatives, some gums, lipids and proteins, mainly due to their high solubility and low viscosity, which are important conditions for the spray-drying process (Quek et al., 2007). These carrier agents may also protect the bioactive compounds of the fruits from oxidation.

In this context, microencapsulation studies using modified starch (Telis and MartínezNavarrete, 2010; Santana et al., 2014; Deng et al., 2014), gum Arabic (Tonon et al., 2011; Santana et al., 2013; Silva et al., 2013), soy protein (Robert et al., 2010; Rascón et al., 2011; Tang and Li, 2013) and whey protein (Adhikari et al., 2009; Bastos et al., 2012; Fang and Bhandari, 2012) were carried out. The literature presents no such study on the binary and ternary mixtures using this carrier to encapsulate jussara pulp.

The purpose of this work was to evaluate the effect of different mixtures of carrier agents on the physicochemical properties of spray-dried jussara powder analyzing for moisture content, water activity, hygroscopicity, solubility, bulk, absolute density and porosity.

\section{MATERIALS AND METHODS}

\subsection{MATERIALS}

Jussara fruit were supplied by farmers from the rural communities in Ubatuba, São Paulo, Brazil. Water was added during pulping (pulp:water ratio 1:2, w/w) and the jussara pulp then packed into plastic bottles $(1 \mathrm{I})$ and immediately frozen. The pulp had to be frozen because it is highly perishable. Table 1 shows the composition of the jussara pulp used in the trials. 
TABLE 1: COMPOSITION OF THE JUSSARA PULP.

\begin{tabular}{|c|c|c|}
\hline Analysis & Mean \pm SD $^{a}$ & Method \\
\hline Moisture (\%) & $79.59 \pm 0.08$ & AOAC (2006) \\
\hline Total protein (\%) & $4.49 \pm 0.05$ & AOAC (2006) \\
\hline Fat $(\%)$ & $19.59 \pm 0.12$ & AOAC (2006) \\
\hline Ash (\%) & $1.03 \pm 0.01$ & AOAC (2006) \\
\hline Total sugar $(\%)$ & $4.62 \pm 1.46$ & By difference \\
\hline Reducing sugar (\%) & $3.20 \pm 0.56$ & AOAC (2006) \\
\hline Total acidity (g citric acid/100 g) & $0.23 \pm 0.02$ & AOAC (2006) \\
\hline $\mathrm{pH}$ & $4.99 \pm 0.07$ & $\mathrm{pH}$ Meter \\
\hline Total soluble solids ( ${ }^{\circ} \mathrm{Brix}$ ) & $10.15 \pm 0.21$ & Bench refractometer \\
\hline Vitamin $\mathrm{C}$ content (mg vitamin $\mathrm{C} / 100 \mathrm{~g}$ ) & $30.59 \pm 0.98$ & AOAC (2006) \\
\hline Anthocyanins (mg/g) & $8.35 \pm 0.36$ & Cinquanta et al. (2002) \\
\hline
\end{tabular}

a Percentage on a wet basis; All data presented as the mean \pm standard deviation $(S D)$ of three replicates $(n=3)$.

The carrier agents used were: modified starch (Hi-Cap 100, National Starch, São Paulo, Brazil), whey protein concentrate (WPC 80, Alibra, Campinas, Brazil) and soy protein isolate (SPI SUPRO® 783, Solae, Barueri, Brazil).

\subsection{SAMPLE PREPARATION}

Before the spray drying process, the jussara pulp was vacuum filtered through porous fabric using a Büchner funnel. This procedure was carried out with the purpose of removing suspended solids to avoid obstruction of the atomizer nozzle of the spray dryer. Different concentrations of binary combinations of the encapsulating matrices containing the jussara extract were subjected to spray drying. The mixture was dissolved in a 'Ultra-Turrax' (IKA T25 D, Staufen, Germany) homogenizer at room temperature and $14,000 \mathrm{rpm}$ for 10 minutes (complete dissolution), and maintained under magnetic agitation during the passage of the solutions through the atomizer nozzle.

\subsection{Microcapsule production and analysis}

The resulting homogenized solutions were immediately fed into the BÜCHI Mini Spray B-290 (Flawil, Switzerland) spray dryer equipped with a two-fluid nozzle atomizer (diameter $7 \mathrm{~mm}$ ). The solutions were fed into the chamber at an inlet drying air temperature of $170{ }^{\circ} \mathrm{C}$ corresponding to an outlet air temperature of $100-110^{\circ} \mathrm{C}$, peristaltic pump rate of $18 \%(5 \mathrm{ml} / \mathrm{min})$, aspirator rate of $90 \%$, spraying air flow rate of $500 \mathrm{l} / \mathrm{h}$, carrier agent concentrations of 1.25 and $2.0(17.5$ and $30 \%) \mathrm{g}$ carrier/g jussara pulp solids and proportions of 17.5 and $30(17.5$ and $30 \%) \mathrm{g}$ protein/100 g carrier. The microcapsules manufactured were stored in sealed plastic bags and placed in desiccators for further analysis. 


\subsubsection{Moisture content and water activity}

The moisture content of the powder was determined gravimetrically using a vacuum oven at $70^{\circ} \mathrm{C}$ to constant weight. The moisture content of the feed solution was determined using a forced air circulation oven at $60{ }^{\circ} \mathrm{C}$ for 24 hours, followed by a vacuum oven at $70{ }^{\circ} \mathrm{C}$ to constant weight (AOAC, 2006). A Decagon equipment (Pawkit model, Aqualab, USA) was used to measure the water activity at $25^{\circ} \mathrm{C}$. All the analyses were carried out in triplicate.

\subsubsection{Hygroscopicity}

The hygroscopicity was evaluated according to Cai and Corke (2000). with some modifications. About $1 \mathrm{~g}$ of sample was placed in aluminum vials, weighed and then equilibrated over a saturated $\mathrm{NaCl}$ solution (providing a relative humidity of $75.3 \%$ ) in a hermetic container at 25 ${ }^{\circ} \mathrm{C}$. The samples were reweighed after one week, and the hygroscopicity expressed as $\mathrm{g}$ of adsorbed moisture/100 $\mathrm{g}$ of solids. The analysis was carried out in triplicate.

\subsubsection{Solubility}

The solubility was determined according to Eastman and Moore (1984), as cited by CanoChauca et al. (2005), with some modifications. $100 \mathrm{ml}$ of distilled $\mathrm{H}_{2} \mathrm{O}$ was transferred to a blender jar. The powder sample (1 g, dry basis) was carefully added to the blender and homogenized at high velocity for $5 \mathrm{~min}$. The solution was placed in a tube and centrifuged at $3000 \times \mathrm{g}$ for $5 \mathrm{~min}$. A $25 \mathrm{ml}$ aliquot of the supernatant was transferred to pre-weighed Petri dishes and immediately oven-dried at $105^{\circ} \mathrm{C}$ to constant weight and the solubility (\%) calculated by weight difference. The analysis was repeated in triplicate.

\subsubsection{Bulk and Absolute Densities}

Approximately $2 \mathrm{~g}$ of powder were placed in a $10 \mathrm{ml}$ graduated cylinder (graduated in 1 $\mathrm{ml}$ units) and the cylinder tapped by hand 50 times. The bulk density was calculated by dividing the mass of powder by the volume it occupied in the cylinder (Goula et al., 2004). The measurements were carried out at room temperature.

The absolute densities of the powders were determined at $25^{\circ} \mathrm{C}$ using a helium Automatic Gas pycnometer (AccuPyc 1330, Micromeritics, Norcross, USA), repeating the analyses five times.

\subsubsection{Porosity}

The porosity was calculated using Equation (1) (Krokida and Maroulis, 1997).

$\varepsilon=1-\frac{\rho_{b}}{\rho_{a}} \times 100$

where $\rho_{b}$ and $\rho_{a}$ are the bulk and absolute densities, respectively.

\section{RESULTS AND DISCUSSION}

\subsection{MOISTURE CONTENT AND WATER ACTIVITY}

The moisture content and water activity are important indexes because they can greatly affect the shelf life of the powders. Water activity is different from moisture content since it measures the availability of free water in a food system, this water being responsible for any biochemical reactions, whereas the moisture content represents the total water content of a food system. Thus, higher water activity results in a shorter shelf life. The water activity values varied from 0.07 to 0.16 (Table 2), all under 0.30 , so the spray dried jussara pulp could be considered stable (Fennema, 1996). 
The moisture content of the powder varied from 0.50 to $0.99 \%$ (Table 2), close to the values reported by Tonon et al. (2009), Barroso et al. (2014) and Santana et al. (2014), working with spray dried açai, linseed oil and pequi pulp powder, respectively. This important property of spray-dried products is an indicator of the adequacy of the drying process. Moreover, a lower residual moisture content limits the ability of the water to act as a plasticizer and to depress the glass transition temperature $\left(T_{g}\right)$. The $T_{g}$ of particles is a function of the moisture content, so the inlet variables become an important factor since they affect powder stickiness and caking. In addition, the $T_{g}$ has been used as an indicator of molecular mobility, which changes the diffusivity of molecular species. In the rubbery state, the molecular mobility of the matrix and the reactants are accelerated, which results in an increased rate of the physicochemical properties of the products (Roos, 2010). In general, a dry food with a moisture content between $3-10 \%$ shows good stability during storage (Klaypradit and Huang, 2008). The results indicated that the lowest moisture content $(p<0.05)$ was obtained for the microcapsules with the composite wall material of $30 \% \mathrm{CAC}+17.5 \% \mathrm{MS}$ :WPC (particle size $D[4,3]-10,93$ ), whereas wall materials with $17.5 \% \mathrm{CAC}+30 \% \mathrm{MS}$ :WPC (particle size $D[4,3]-14.20$ ) yielded the largest $(p<0.05)$ particles. The lower moisture content with $30 \% C A C+17.5 \% M S: W P C$ could be related to the amount of water applied to the aqueous phase during preparation and the smaller variation in particle size of the finished product, which is an index of crust formation time. The crust encloses water within the particle, so that moisture cannot easily be evaporated from the interior. With a greater amount of WPC in the carrier $(17.5 \% \mathrm{CAC}+30 \% \mathrm{MS}$ :WPC) the particles could migrate more rapidly to the droplet surface and form a continuous glass phase earlier than in the case of a smaller amount of WPC in the carrier. The crust generated on the droplet surface is subsequently transformed to a tough leathery-like skin and hinders moisture evaporation. It acts as a barrier against moisture evaporation, thus generating capsules with higher moisture contents. Rosenberg and Sheu (1996) reported a similar observation for the effect of carriers on crust formation during the microencapsulation of volatiles in whey proteinbased wall systems.

\section{TABLE 2: WATER ACTIVITY, MOISTURE CONTENT, HYGROSCOPICITY AND SOLUBILITY OF JUSSARA PULP POWDERS PRODUCED WITH MIXTURES OF DIFFERENT CARRIER AGENTS.}

\begin{tabular}{ccccc}
\hline Type & Water activity & Moisture (\%) & Hygroscopicity (\%) & Solubility (\%) \\
\hline $30 \% C A C+17.5 \% M S: W P C$ & $0.16 \pm 0.01^{\mathrm{c}}$ & $0.50 \pm 0.03^{\mathrm{a}}$ & $8.26 \pm 0.01^{\mathrm{b}}$ & $78.68 \pm 0.88^{\mathrm{a}}$ \\
\hline $17.5 \% \mathrm{CAC}+30 \% \mathrm{MS}: W P C$ & $0.07 \pm 0.01^{\mathrm{a}}$ & $0.99 \pm 0.11^{\mathrm{c}}$ & $3.62 \pm 0.03^{\mathrm{a}}$ & $78.51 \pm 2.07^{\mathrm{a}}$ \\
\hline $30 \% \mathrm{CAC}+17.5 \% \mathrm{MS}: \mathrm{SPI}$ & $0.09 \pm 0.01^{\mathrm{b}}$ & $0.72 \pm 0.10^{\mathrm{b}}$ & $4.85 \pm 0.01^{\mathrm{ab}}$ & $78.67 \pm 0.65^{\mathrm{a}}$ \\
\hline $17.5 \% \mathrm{CAC}+30 \% \mathrm{MS}: \mathrm{SPI}$ & $0.08 \pm 0.01^{\mathrm{ab}}$ & $0.93 \pm 0.13^{\mathrm{c}}$ & $4.17 \pm 0.03^{\mathrm{ab}}$ & $79.67 \pm 1.55^{\mathrm{a}}$ \\
\hline
\end{tabular}

$\mathrm{CAC}=$ carrier agent concentration; $\mathrm{MS}=$ modified starch; WPC=whey protein concentrate; SPI=soy protein isolate. $a, b, c=$ Means in the same column followed by the same superscripts are not significantly different at $p<0.05$ by Tukey's test.

\subsection{HYGROSCOPICITY AND SOLUBILITY}

The hygroscopicity of the capsules varied from a minimum value of $3.62 \mathrm{~g}$ water adsorbed/100 g solids to a maximum value of $8.26 \mathrm{~g}$ water adsorbed/100 $\mathrm{g}$ solids (Table 2 ). These values were lower than those obtained by Moreira et al. (2009) and by Tonon et al. (2008) for acerola 
and açai pulps, respectively. Jussara pulp has a higher fat content than acerola and açai pulps and hence exhibits a less hygroscopic behaviour. Water adsorption is a critical factor for the shelf life of powder microparticles because water can affect the oxidation process. Continuous water adsorption could also result in caking of the powders due to the formation of liquid bridges between the powder particles. Since the particles are soluble in water, the liquid bridges will contain their components, which will increase the viscosity of the liquid bridges, causing them to adhere and bind strongly (Listiohadi et al., 2005; Brotel et al., 2014).

Particles with lower moisture contents are more hygroscopic, i.e., they have a greater capacity to adsorb moisture from the surrounding air (Santana et al., 2013). Table 2 shows the inverse relationship between powder moisture content and hygroscopicity, and the same behaviour was reported by Goula et al. (2004) in their work on the spray drying of tomato pulp.

The spray drying of fruit requires knowledge of its properties and the factors affecting the process. Solubility problems occur when foods are submitted to high temperatures, especially in products with high solids concentrations (Cano-Chauca et al., 2005).

According to Table 2, the experimental values for the solubility of the spray dried jussara pulp powders ranged between 78.51 and $79.67 \%$, similar to the values found for spray dried açai and mango juices (Tonon et al., 2008; Cano-Chauca et al., 2005) and higher than spray dried pomegranate juice (Vardin and Yasar, 2012). Statistically there was no significant difference in the solubility of microcapsules as affected by tween. The powders showed good solubility despite the hydrophobic nature of the core material and this variable was also strongly affected by the nature of the carrier material (Yousefi et al., 2011; Brotel et al., 2014). The materials used in this work (carbohydrates and proteins) are known to exhibit good solubility in water at various concentrations, a fact that could contribute to the lack of differences amongst the treatments.

\subsection{BULK AND ABSOLUTE DENSITIES AND POROSITY}

Knowledge of the density of a product is important for processing, packaging, storage and transport, since it indicates how much material, by weight, a given volume may contain. Low bulk density of a product is not attractive, resulting in a larger volume for packaging (Barroso et al., 2014). In addition, the product will be in contact with a greater amount of air, increasing the possibility of oxidation of the food (Barbosa-Canóvas and Juliano, 2005; Cano-Chauca et al., 2005).

In this experiment the bulk density varied from a minimum value of $0.45 \mathrm{~g} / \mathrm{cm}^{3}$ to a maximum value of $0.50 \mathrm{~g} / \mathrm{cm}^{3}$ (Table 3 ). This value was similar to those obtained for microcapsules of vegetable oil (Turchiuli, 2005), linseed oil (Carneiro et al., 2013), essential oregano oil (Brotel et al., 2014) and essential rosemary oil (Fernandes et al., 2013). On the other hand, Caparino et al. (2012) reported higher values for the bulk density of mango pulp powder than for jussara pulp powder.

The absolute densities were $1.21 \mathrm{~g} / \mathrm{cm}^{3}, 1.11 \mathrm{~g} / \mathrm{cm}^{3}, 1.19 \mathrm{~g} / \mathrm{cm}^{3}$ and $1.16 \mathrm{~g} / \mathrm{cm}^{3}$ for the $30 \% \mathrm{CAC}+17.5 \% \mathrm{MS}: \mathrm{WPC}, 17.5 \% \mathrm{CAC}+30 \% \mathrm{MS}: \mathrm{WPC}, 30 \% \mathrm{CAC}+17.5 \% \mathrm{MS}: \mathrm{SPI}$ and 17.5 $\% \mathrm{CAC}+30 \% \mathrm{MS}: \mathrm{SPI}$ treatments, respectively (Table 3 ). Similar values were obtained by Ferrari et al. (2012) and Santana et al. (2013), evaluating blackberry and pequi pulp powders produced by spray drying. The absolute density corresponds to the real density of the solids and does not consider the spaces between the particles, in contrast to the bulk density, which takes all these spaces into account. These results are lower than particle densities of most food powders, which are about 1.40 $\mathrm{g} / \mathrm{cm}^{3}$ (Barbosa-Canóvas and Juliano, 2005). Porosity is an important property for microcapsules because encapsulated material is susceptible to oxidation reactions. The porosity of the jussara pulp powder varied from a minimum value of $55.09 \%$ to a maximum value of $62.74 \%$ (Table 3). Spherical particles pack better and thus have the highest bulk densities and porosity values (Reineccius, 2004). Similar results were obtained by Osório and Carriazo (2011) and by Horuz et al. (2012), studying guava and pomegranate juice powders, respectively. 


\section{TABLE 3: BULK AND ABSOLUTE DENSITIES AND POROSITY OF JUSSARA PULP POWDERS PRODUCED WITH A MIXTURE OF DIFFERENT CARRIER AGENTS.}

\begin{tabular}{|c|c|c|c|}
\hline Type & Bulk density $\left(\mathrm{g} / \mathrm{cm}^{3}\right)$ & Absolute density $\left(\mathrm{g} / \mathrm{cm}^{3}\right)$ & Porosity (\%) \\
\hline $30 \% \mathrm{CAC}+17.5 \% \mathrm{MS}: W P C$ & $0.45 \pm 0.02^{\mathrm{a}}$ & $1.21 \pm 0.00^{d}$ & $62.74 \pm 0.01^{\mathrm{b}}$ \\
\hline $17.5 \% \mathrm{CAC}+30 \% \mathrm{MS}: W P C$ & $0.50 \pm 0.01^{b}$ & $1.11 \pm 0.01^{\mathrm{a}}$ & $55.09 \pm 0.01^{a}$ \\
\hline $30 \% \mathrm{CAC}+17.5 \% \mathrm{MS}: \mathrm{SPI}$ & $0.47 \pm 0.01^{\mathrm{ab}}$ & $1.19 \pm 0.00^{c}$ & $60.99 \pm 0.01^{b}$ \\
\hline $17.5 \% \mathrm{CAC}+30 \% \mathrm{MS}: \mathrm{SPI}$ & $0.49 \pm 0.01^{b}$ & $1.16 \pm 0.01^{b}$ & $57.39 \pm 0.02^{a}$ \\
\hline
\end{tabular}

\section{CONCLUSIONS}

The wall materials used in this study were found to present properties of interest for the production of spray-dried microparticles containing jussara pulp. The solubility of the particles, which is an important factor for the use of powdered materials, was not affected by the partial substitution of WPC by SPI. Moreover, the presence of WPC at the concentration of $30 \% \mathrm{CAC}+17.5 \% \mathrm{MS}$ :WPC, improved the bulk density and moisture content. The importance of using protein as the secondary wall material was reaffirmed in this work, which demonstrated how these components complemented the characteristics of the wall materials used to produce jussara pulp microparticles. The use of WPC or SPI together with MS is a good alternative in the spray drying of jussara pulp. In general, the results obtained in this study indicated that good quality powders could be produced by spray drying. This demonstrated that the results could be of use in food preparations, such as to obtain novel and inexpensive sources of natural jussara flavorings in the production of dry mixes, beverages, desserts and other products, as well as in the reconstitution of the juice itself. The product could also be of interest to cosmetic companies looking for novel and inexpensive sources of natural pigments to be used as colorants and flavorings.

\section{RESUMO}

\section{CARACTERIZAÇÃO FÍSICO-QUÍMICA DA POLPA DE JUÇARA EM PÓ POR SPRAY- DRYING}

O presente estudo foi realizado para avaliar os efeitos de diferentes misturas de agentes carreadores (AC) (amido modificado - AM acrescido de concentrado proteico de soro de leite - CPL ou isolado proteico de soja - IPS) sobre as características das microcápsulas contendo polpa de juçara em pó. Quatro tratamentos, 30\% CAC + 17,5\% AM:CPL; $17,5 \%$ CAC + 30\% AM:CPL; 30\% CAC + 17,5\% AM:IPS; e 17,5\% CAC + 30\% AM:IPS, foram avaliados, nos quais $\mathrm{CAC}=$ concentração de agente carreador ( $\mathrm{g}$ carreador/g sólidos de polpa de juçara) e proporções AM:CPL e AM:IPS em gamas de proteína (CPL ou IPS) por $100 \mathrm{~g}$ de carreador. A solubilidade das partículas não foi afetada pelo material de parede, atingindo valores médios de $78 \%$. A 
concentração de $30 \%$ CAC + 17,5\% AM:CPL melhorou o conteúdo de umidade e densidade bulk. CPL e IPS mostraram ser boas alternativas de materiais de parede secundários para polpa de juçara, em conjunto com AM.

PALAVRAS-CHAVE: EUTERPE EDULIS MARTIUS; SPRAY DRYING; CONCENTRADO PROTEICO DE SORO DE LEITE; AMIDO MODIFICADO; ISOLADO PROTEICO DE SOJA.

\section{REFERENCES}

1 Adhikari, B.; Howes, T.; Wood, B. J.; Bhandari, B. R. The effect of low molecular weight surfactants and proteins on surface stickiness of sucrose during powder formation through spray drying. Journal of Food Engineering, v.94, n.2, p. 135-143, 2009.

2 AOAC (2006). Official methods of analysis of the Association of Official Analytical Chemists, (18th ed.). Gaithersburg, USA: Association of Official Analytical Chemists.

3 Barbosa-Canóvas, G.V.; Juliano, P. Physical and chemical properties of food powders. In: ONWULATA, C. (Ed.). Encapsulated and powdered foods, Boca Raton: Taylor \& Francis, Chapter 3, p. 39-71, 2005.

4 Barroso, A. K. M.; Pierucci, A. P. T. R.; Freitas, S. P.; Torres, A. G.; Rocha-Leão, M. H. M. Oxidative stability and sensory evaluation of microencapsulated flaxseed oil. Journal of Microencapsulation, v.31, n.2, p. 193-201, 2014.

5 Bastos, D. D. S.; Gonçalves, M. P.; Andrade, C. T.; Araújo, K. G. L.; Rocha-Leão, M. H. M. Microencapsulation of cashew apple (Anacardium occidentale, L.) juice using a new chitosan-commercial bovine whey protein isolate system in spray drying. Food and Bioproducts Processing, v.90, n.4, p. 683-692, 2012.

6 Bhandari, B. R.; Datta, N.; Howes, T. Problems associated with spray drying of sugar-rich foods. Drying Technology, v.15, p. $671-684,1997$

7 Borges, G. S. C.; Vieira, F. G. K.; Copetti, C.; Gonzaga, L.V.; Fett, R. Optimization of the extraction of flavanols and anthocyanins from the fruit pulp Euterpe edulis using the response surface methodology. Food Research International, v.44, p. 708-715, 2011.

8 Brotel, D.A.; Fernandes, R.V.B.; Borges, S.V.; Yoshida, M.I. Influence of wall matrix systems on the properties of spraydried microparticles containing fish oil. Food Research International, v.62, p. 344-352, 2014.

9 Cai, Y.Z.; Corke, H. Production and properties of spray-dried Amaranthus betacyanin pigments. Journal of Food Science, v.65, n.6, p. 1248-1252, 2000.

10 Cano-Chauca, M.; Stringheta, P. C.; Ramos, M. A.; Cal-Vidal, J. Effect of the carriers on the microstructure of mango powder obtained by spray drying and its functional characterization. Innovative Food Science Emergencies Technology, v.5, n.4, p. 420-428, 2005.

11 Caparino; O.A., Tang; J., Nindo; C.I., Sablani; S.S. Powers, J.R.; Fellman, J.K. Effect of drying methods on the physical properties and microstructures of mango (Philippine Carabao var.) powder. Journal Food Engineering, v.111, p. 135-148, 2012.

12 Carneiro, H. C. F.; Tonon, R. V.; Grosso, C. R. F.; Hubinger, M. D. Encapsulation efficiency and oxidative stability of flaxseed oil microencapsulated. Journal of Food Engineering, v.115, n.4, p. 443-451, 2013.

13 Cinquanta, L.; Dimatteo, M.D.; Esti, M. Physical pre-treatment of plums (Prunus domestica). Part 2. Effect on the quality characteristics of different prune cultivars. Food Chemistry, v.79, n.2, p. 233-238, 2002.

14 Deng, X-X.; Chen, Z.; Huang, Q.; Fu, X.; Tang, C-H. Spray-drying microencapsulation of $\beta$-carotene by soy protein isolate and/or OSA-modified starch. Journal of Applied Polymer Science, DOI: 10.1002/APP.40399, 2014.

15 Fang, Z.; Bhandari, B. Comparing the efficiency of protein and maltodextrin on spray drying of bayberry juice. Food Research International, v.48, n.2, p. 478-483, 2012

17 Fernandes, R.V.B.; Borges, S.V.; Botrel, D.A. Influence of spray drying operating conditions on microencapsulated rosemary essential oil properties. Food Science and Technology, v.33, n.1, p. 171-178, 2013. 
18 Ferrari, C.C.; Germer; S.P.M.; Alvim, I.D.; Vissotto, F.Z.; Aguirre, J.M. Influence of Carrier agents on the physicochemical properties of blackberry powder produced by spray drying. International Journal of Food Science and Technology, v.47, p. 1237-1245, 2012.

19 Goula, A.M.; Adamopoulos, K.G.; Kazakis, N.A. Influence of spray drying conditions on tomato powder properties. Drying Technology, v.22, n.5, p. 1129-1151, 2004

20 Horuz, E.; Altan, A.; Maskan, M. Spray drying and process optimization of unclarified pomegranate (Punica granatum) juice. Drying Technology, v.30, p. 787-798, 2012.

21 Klaypradit, W.; Huang, Y. W. Fish oil encapsulation with chitosan using ultrasonic atomizer. LWT - Food Science Technology, v.41, p. 1133-1139, 2008.

22 Masters, K. Spray Drying Handbook, 5th ed.; Longman Scientific and Technical: London, 1991.

23 Krokida, M.K.; Maroulis, Z.B. Effect of drying method on shrinkage and porosity. Drying Technology, v.15, n.10, p. 24412458, 1997.

24 Listiohadi, Y.D.; Hourigan, J.A.; Sleigh, R.W.; Steele, R.J. An exploration of the caking of lactose in whey and skim milk powders. Australian Journal of Dairy Technology, v.60, p. 207-213, 2005.

25 Moreira, G.E.G.; Costa, M.G.M.; Souza, A.C.R.; Brito, E.S.; Medeiros, M.F.D.; Azeredo, H.M.C. Physical properties of spray dried acerola pomace extract as affected by temperature and drying aid. LWT-Food Sci. Technology, v.42, p. 641645, 2009.

26 Osorio, C.; Carriazo, J. G. Thermal and structural study of guava (Psidium guajava L) powders obtained by two dehydration methods. Química Nova, v.34, n.4, p. 636-640, 2011.

27 Quek, S. Y.; Chok, N. K.; Swedlund, P. The physicochemical properties of spray dried watermelon powders. Chemical Engineering and Processing, v.46, n.5, p. 386-392, 2007.

28 Rascón, M. P.; Beristain, C. I.; García, H. S.; Salgado, M. A. Carotenoid retention and storage stability of spray-dried encapsulated paprika oleoresin using gum Arabic and Soy protein isolate as wall materials. LWT - Food Science and Technology, v.44, n.2, p. 549-557, 2011.

29 Ré, M. I. Microencapsulation by spray drying. Drying Technology, v.16, p. 1195-1236, 1998.

30 Reineccius, G.A. The spray drying of food flavors. Drying Technology, v.22, n.6, p. 1289-1324, 2004

31 Robert, P.; Gorena, T.; Romero, N.; Sepulveda, E.; Chavez, J.; Saenz, C. Encapsulation of polyphenols and anthocyanins from pomegranate (Punica granatum) by spray drying. International Journal of Food Science and Technology, v.45, n.7, p. 1386-1394, 2010.

32 Roos, Y.H. Glass transition temperature and its relevance in food processing. Annu. Reviews Food Sci. Technology, v.1, p. $469-496,2010$

33 Rosenberg, M.; Sheu, T-Y. Microencapsulation of volatiles by spray-drying inwhey protein-based wall systems. International Dairy Journal, v.6, n.3, p. 273-284, 1996.

34 Santana, A. A.; Kurozawa, L. E.; Oliveira, R. A.; Park, K. J. Influence of process conditions on the physicochemical properties of pique powder produced by spray drying. Drying Technology, v.31, n.7, p. 825-836, 2013.

35 Santana, A.A.; Oliveira, R.A.; Kurozawa, L.E.; Park, K.J. Microencapsulation of pequi pulp by spray drying: use of modified starches as encapsulating agent. Engenharia Agrícola, v.34, n.5, p. 980-991, 2014.

36 Silva, M. V. V.; Sales, J. F.; Silva, F. G.; Rubio Neto, A.; Alberto, P. S.; Pereira, F. D. The influence of moisture on the in vitro embryo germination and morphogenesis of babassu (Orbignya phalerata Mart.). Acta Science, v.34, n.4, p. 453458, 2013.

37 Tang, C. H.; Li, X. R. Microencapsulation properties of soy protein isolate and storage stability of the correspondingly spray-dried emulsions. Food Research International, v.52, n.1, p. 419-428, 2013.

38 Telis, V. R. N.; Martínez-Navarrete, N. Application of compression test in analysis of mechanical and color changes in grapefruit juice powder as related to glass transition and water activity. LWT - Food Science and Technology, v.43, n.5, p. 744-751, 2010

39 Tonon, R.V.; Brabet, C.; Pallet, D.; Brat, P.; Hubinger, M.D. Physical and morphological characterization of açaí (Euterpe oleraceae Mart.) powder produced with different carrier agents. International Journal Food Science and Technology, v.44, p. 1950-1958, 2011. 
40 Tonon, R.V.; Brabet, C.; Hubinger, M. D. Influence of process conditions on the physicochemical properties of açai (Euterpe oleraceae Mart.) powder produced by spray drying. Journal Food Engineering, v.88, p. 411-418, 2008.

41 Tonon, R. V.; Brabet, C.; Pallet, D.; Brat, P.; Hubinger, M. D. Physical and morphological characterization of açaí (Euterpe oleraceae Mart.) powder produced with different carrier agents. International Journal Food Science and Technology, v.44, p. 1950-1958, 2009.

42 Turchiuli, C.; Fuchs, M.; Bohin, M.; Cuvelier, M.E.; Ordonnaud, C.; Pevratmaillard, M.N.; Dumoulin, E. Oil encapsulation by spray drying and fluidized bed agglomeration. Innovative Food Science and Emerging Technologies, v.6, n.1, p. 2935, 2005.

43 Vardin, H.; Yasar, M. Optimisation of pomegranate (Punica Granatum L.) juice spray-drying as affected by temperature and Maltodextrin content. International Journal Food Science and Technology, v.47, n.1, p.167-176, 2012.

44 Yousefi, S.; Emam-Djomeh, Z.; Mousavi, S.M. Effect of carrier type and spray drying on the physicochemical properties of powdered and reconstituted pomegranate juice (Punica granatum L.). Journal of Food Science and Technology, v.48, p. $677-684,2011$

\section{ACKNOWLEDGEMENTS}

The authors are grateful to the Brazilian Government Agency CAPES for financial support. 